\title{
FLUCTUATION RANGE OF THE CONCENTRATION OF AIRBORNE Alternaria CONIDIOSPORES SAMPLED AT DIFFERENT GEOGRAPHICAL LOCATIONS IN POLAND (2010-2011)
}

\author{
Idalia Kasprzyk ${ }^{1}$, Aneta Sulborska², Małgorzata Nowak ${ }^{3}$, Agata Szymańska ${ }^{3}$, \\ Joanna Kaczmarek ${ }^{4}$, Weronika Haratym² ${ }^{2}$,Elżbieta Weryszko-Chmielewska ${ }^{2}$, \\ Małgorzata Jędryczka ${ }^{4 *}$
}

\author{
${ }^{1}$ University of Rzeszów, Rzeszów, Poland \\ ${ }^{2}$ University of Life Sciences, Lublin, Poland \\ ${ }^{3}$ A. Mickiewicz University of Poznań, Poznań, Poland \\ ${ }^{4}$ Institute of Plant Genetics, Polish Academy of Sciences, Poznań, Poland \\ * e-mail: mjed@igr.poznan.pl
}

Received: 12.12.2012

Abstract

Knowledge of seasonal and diurnal fluctuations of allergenic and phytopathogenic fungal spores in the air and the determination of the influence of weather and environmental parameters on spore concentrations are of great practical use in control of both human and animal health as well as plant diseases. The aim of this study was to evaluate the dynamics of the occurrence of Alternaria spores in the air at three sites located in different geographical regions of Poland. The study was done from 15 April to 30 September in 2010-2011 in Rzeszów (Carpathian Foothills, south-east Poland), Lublin (Lublin Upland, central east), and Poznań (central west); the distance between the experimental sites ranged from 138 to $441 \mathrm{~km}$. To assess the concentration of Alternaria spores, the volumetric method was used. In both years, the highest concentration of spores was observed in Poznań and the lowest in Rzeszów. In 2010 the annual total, monthly total and maximum spore concentration were higher than in 2011 at all monitoring sites. The greatest concentration of Alternaria spores was recorded in August, followed by July. High spore concentrations were also noted at the beginning of September. The differences in daily concentrations, average concentrations and cumulative numbers of spores were statistically significant. The reasons for this can be related not only to weather parameters, which is often raised in the literature, but also to the type of landscape. Landscape and geobotanical conditions of Great Poland and Carpathian Foothills greatly differ. In both years, the highest number of Alternaria spores was found in Poznań - the city with the highest urbanization factor and the capital of the region with large-scale farming, connected with the intensification of agricultural practices.

Key words: aerobiology, Alternaria spp., fungal spores, Poland, seasonality

\section{INTRODUCTION}

Fungal spores belong to biological particles most often present in the air and hence numerous studies have been undertaken on their concentrations in different biogeographical regions and climatic zones (Adams, 1964; Nikkels et al. 1996; Corden et al. 2003; Stennett and Beggs, 2004; Stępalska and Wołek, 2005; Tomassetti et al. 2009; Grinn-Gofroń and Strzelczak, 2012). Monitoring of concentrations of fungal spores in air samples have also been undertaken in Poland, mainly in the region of Małopolska in south of the country and Pomorze in the north-west ( $\mathrm{S}$ tę p a ls k a et al. 1999; Kon opińska, 2004; S tępalska and Wołek, 2005; Gri in - G ofroń, 2008; Gri in - G of roń and Rapiejko, 2009; Stępalska et al. 2012). The concentration of spores in air samples highly depend on temperature and humidity and can be dramatically changed by weather events (Gri in - G ofron and Strzelczak, 2012) but it is also affected by other factors, such as air pollutants (G r i n n - G o f r o ń et al. 2011). The knowledge about meteorological conditions and air pollution allows one to predict the concentration of Alternaria spores using artificial neural network forecasting models ( $\mathrm{Gr}$ in $\mathrm{n}-\mathrm{G}$ ofroń and Strzelczak, 2008).

Numerous papers concentrate on aerobiological aspects of airborne fungal spores, such as their presence/absence, start and end of the season, spore concentration and the number of days exceeding cer- 
tain thresholds (Gravese n, 1979; Crook, 1994; Icenhour and Levetin, 1997; Myszkowska et al. 2002; Corden et al. 2003; Escuredo et al. 2011). These parameters are of great importance from the medical point of view, because numerous fungal spores produce allergenic proteins that can cause immunotoxic diseases, such as asthma (D' A m a to and S pieksma, 1995; Dutkiewicz, 1997; B u sh and Portnoy,2001). Researchers report increasing numbers of patients with respiratory allergy, in particular children (E m e r y k et al. 2004).

The genus Alternaria Nees ex Wallroth contains over 300 species, out of which fewer than 40 are well described. The fungi of this genus are ubiquitous and they can be found in all zones and climates ( $\mathrm{S}$ a k i y a $\mathrm{n}$ and Inceo lu, 2003; Damialis and Gioulekas, 2006; Mikali naité et al. 2009; GrinnG o fro ń, 2009). In the air, they are present only in the conidial stage (anamorph). The generative stage (teleomorph) is formed occasionally; it belongs to the genus Lewia Barret et Simons (O g ó r e k et al. 2011).

Most papers on aeromycology report that spores of Alternaria are present both in temperate and hot climates, which is associated with the broad range of temperature and humidity, allowing undisturbed development and sporulation of this fungus. The ratio of Alternaria spores in air samples differed from a few to tens of percent (R o s a s et al. 1990; M it a k a k is et al. 1997, 2001; Kas przyk et al. 2004; S te n$\mathrm{net}$ t and B e g g s , 2004; M a y a - Manzano et al. 2012). Other fungal types, like Cladosporium, often prevailed in the air, but it is the spores of the genus Alternaria that are repeatedly reported as the most harmful among fungal species responsible for respiratory allergies (Srivastawa and Wadhwani, 1992; I c e n hour and Levetin, 1997; B u sh and Portnoy, 2001; Licorish et al. 1985). According to R a pi ejko et al.(2004), the concentration of 80 conidiospores per $1 \mathrm{~m}^{3}$ may cause the first disease symptoms in sensitive patients. The symptoms are partially caused by secondary metabolites produced by Alternaria. This genus is known for producing over 70 toxic compounds, such as alternariol or tenuazonic acid, which may have adverse effects on human health and life comfort (W o o d y and C h u, 1992; O s try, 2008; O g ó r e k et al. 2011). Exposure to Alternaria toxins was linked to a variety of adverse health effects ( $\mathrm{Li} \mathrm{u}$ et al. 1992). The studies done in China suggested that the most common saprotrophic species A. alternata may be a factor in the etiology of esophageal cancer (D o n g et al. 1987; Z he n et al. 1991). These threatening data were further supported by the studies of Y e kele r et al. (2001) who observed precancerous changes in esophageal mucosa of mice eating fodder containing tenuazonic acid.
Many species of the genus Alternaria belong to the most notorious pathogens and saprophytes of plants, causing at least $20 \%$ of agricultural spoilage. The pathogens infect potato, tomato, root vegetables, cereals, oilseed rape and numerous fruit leading to the decrease of seed or fruit yield and their quality (F r e n cel et al. 1991; Corden et al. 2003; Gannibal and Gasich, 2009; Escuredo et al. 2011). A nondestructive thermographic study revealed that leaves of oilseed rape infected with A. brassicae and A. brassicicola - the species pathogenic to Cabbages and oileaced rape, had a temperature higher by up to $3.5^{\circ} \mathrm{C}$ comparing to healthy leaves (B aranowski et al. 2009). It shows that plants infected by Alternaria are subjected to great biotic stress, resulting in dramatic changes of their physiology. This explains why severe yield losses in B. oleracea may reach $86 \%$ (HumphersonJ o n e s, 1989). This situation has little chance to alter in the near future, as no source of substantial resistance to Alternaria has been found by now ( $\mathrm{N} \mathrm{ow} \mathrm{i} \mathrm{k} \mathrm{i}$ et al. 2012). High levels of plant infestation by pathogenic and saprotrophic Alternaria species imply high numbers of their conidiospores in the air, posing a constant threat to human and animal health.

Our studies aimed at evaluation of the dynamics of Alternaria spore concentration in three regions of Poland, differing in geographical location, geobotanical character and landscape structure. The null hypothesis assumed no differences between monthly sums of spores and mean spore counts between the experimental sites.

\section{MATERIALS AND METHODS}

\section{Monitoring sites}

The monitoring was done in three geographic regions of Poland: Great Poland, Lublin Upland and Carpathian Foothills. These regions greatly differ in geobotanical properties, climate and the type of landscape.

Rzeszów is the capital and the largest urban area of the province of Carpathian Foothills. It is located in south-east Poland. The city is situated in the Rzeszow Foothills at an altitude of $220 \mathrm{~m}$ above the sea level, on the banks of the Wisłok river. The close proximity of the Carpathian mountains has a major influence on local climate. Summers are long and hot, autumns are relatively warm, most of winters are not very severe, but the outskirts of the region are more snowy and frosty. Mean annual precipitation is $734 \mathrm{~mm}$ and mean annual temperature is $8.8^{\circ} \mathrm{C}$. The warmest month is July $\left(17.5^{\circ} \mathrm{C}\right)$, while the coldest one is January $\left(-4.6^{\circ} \mathrm{C}\right)$. The average growing season ranges from 215 to 220 days. Forest area covers $39.8 \%$ of the voivodship, which ranks it second among all the provinces of 
our country. The percentage of developed and urbanized land of the Rzeszów district is 5.3\% (www.mprn. $\mathrm{pl}$ ). The city is surrounded by a mosaic of farmland and forest, with the prevalence of arable crops. The flora of the city is under strong pressure of humans and most plant communities are a result of human activities. The landscape of Rzeszów is dominated by green parks. In addition, its green areas are urban lawns, home gardens and roadsides. Monitoring with a spore sampler was done in the center of Rzeszów (N 5001'45", E $\left.22^{\circ} 00^{\prime} 57^{\prime \prime}\right)$.

Lublin is located in central east of Poland, on the northern edge of the Lublin Upland at an altitude of 163-238 m above the sea level. It is the capital of the province, situated on the Bystrzyca river that is flowing through the city from the south to the north-east. The climate of this region is influenced by masses of continental air. The growing season lasts approximately 215 days (Woś, 1999). Mean annual air temperature in 1951-2010 was $8.2^{\circ} \mathrm{C}$. The coldest month of the year is January, with its mean temperature $-2.8^{\circ} \mathrm{C}$, while the warmest month is July (mean temperature $19.0^{\circ} \mathrm{C}$ ). Over the last 60 years, the annual total precipitation was $551 \mathrm{~mm}$. The maximum rainfall was recorded in July $(79 \mathrm{~mm})$ and the minimum snowfall $(28 \mathrm{~mm})$ was in January (Piotrow ska and Kas zew ski, 2011). Forest area covers $23.7 \%$ of this region. The percentage of developed and urbanized land in this district is $2.6 \%$ (www.mprn.pl). Within the city of Lublin, there are three mixed forests with a predominance of mixed oak and pine. The city has several parks and public gardens as well as private gardens and allotments used for leisure - gardening and grass lawns. The flora of Lublin is composed of diverse trees and shrubs as well as grasslands. They are also located in the vicinity of the monitoring site. The spore sampler was located on the roof of a building in the city center (N 51 ${ }^{\circ} 14^{\prime} 37^{\prime \prime}$, E 2232'25").

Poznan (N 52 $24^{\prime}$, E16 ${ }^{\circ} 56^{\prime}$ ) is located in the central-west part of Poland in the valley of the Warta river. It is the capital of the Province of Great Poland (Wielkopolska). According to physico-geographical regions of the country, it belongs to Southbaltic Lake District and the macroregion of Great Poland Lakeland. The city is located in the lowlands, at an altitude of approximately $80-100 \mathrm{~m}$. City forest habitats are dominated by oak and hornbeam, willows and poplars prevail in the valley of the Warta river, whereas pine and mixed forests dominate on poor soils. Forests cover about $23 \%$ of the district, while developed and urbanized land accounts for $8.2 \%$ (www.mprn.pl). The spore sampler was located on the roof of the Department of Biology in Morasko (N 52 27', E 16 $55^{\prime}$ ') at the campus of the Adam Mickiewicz University, $6 \mathrm{~km}$ from the city center. Morasko is a peripheral part of
Poznań, situated on the northern border of the city. It is a relatively large, but poorly urbanized area. In close distance from the north and north-east of the University campus, a single-family housing area composed of detached and semi-detached houses is located, whereas the southern part is occupied by a housing estate. The remaining area is occupied by meadows, coniferous forests, groups of leafy trees as well as agricultural fields with cereals or oilseed rape and also by wastelands.

The highest distance measured in a straight line is between Poznań and Rzeszów (441 km) as well as between Poznań and Lublin (408 km), whereas between Lublin and Rzeszów the distance is $138 \mathrm{~km}$.

\section{Methodology of aerobiological studies}

Spore trapping was done constantly, 24 hours round, from 15 April to 30 September in 2010 and 2011. Monitoring was performed using Hirst-type volumetric VPPS 2000 samplers (Lanzoni, Bologna, Italy). The samplers were placed on buildings at the following heights: Rzeszów - $12 \mathrm{~m}$, Lublin and Poznań - $18 \mathrm{~m}$. Additional supports raised the traps above the roof level, allowing an undisturbed air flow. The devices actively sucked 10 liters of air per minute through a narrow orifice $(2 \times 14 \mathrm{~mm})$. Inside the spore trap, a drum rotated moving at a constant speed of 2 $\mathrm{mm}$ per hour. It was covered by a Melinex tape coated with vaseline dissolved in toluene (Poznań) or silicone (Lublin and Rzeszów). Airborne particles present in sampled air - mainly fungal spores and pollen grains - were deposited on this sticky substance. A full rotation of the drum lasted seven days. After removing the tape from the revolving drum, it was cut into seven fragments (48 mm long) and microscope slides were prepared and carefully studied for the presence of Alternaria spores. The spores were counted along horizontal strips. Only spores typical for the genus Alternaria were counted. The number of spores was multiplied by a factor depending on the observed surface of a microscope slide and the result was expressed as the average daily concentration of fungal spores per $1 \mathrm{~m}^{3}$ of air (L a c e y and W e s t, 2006). The samplers were operating constantly; in rare cases of sampler blockage or disturbed work, gaps in the data were filled using an interpolation method.

\section{Data analysis}

The results were analyzed using selected mathematical and statistical methods. The sum of spores in the studied period was calculated. Fluctuations of spores in air were presented as a 5-day moving average. The chi-square test verified the null hypothesis of no differences in frequency distribution of monthly sums of spores between sites. The non-parametric test of Kruskal-Wallis was used to compare the means, 
despite of the lack of variance homogeneity (Brown-Forsyth test). The degree of similarity of fluctuations of spore concentrations in the air during the season was assessed by Spearman's rank correlation coefficients $\left(r_{s}\right)$. The level of significance was studied at $\leq 0.05$.

\section{RESULTS}

\section{Rzeszów}

From the beginning of June 2010, the daily concentration of Alternaria spores slowly increased (Fig. 1). A rapid increase of daily spore concentrations occurred in mid-July. The highest spore concentration was observed in mid-July 2010. After a two-week period of decline, the concentration of spores rapidly increased. In four days the concentration of Alternaria spores again increased nearly to the previous level and reached the top value on 1 August 2010. The second period of high spore concentration lasted until mid-August. In these months, there was more than $80 \%$ of the total amount of spores. Then, the concentration of spores gradually decreased, with the exception of a small peak in the third decade of August. In this year, the value of kurtosis was highly positive, which means a sudden increase in spore concentration, greater than the normal distribution.

In 2011 the fluctuation of Alternaria spore concentration in the air was more erratic than in the previous year. The value of kurtosis was low, as compared to the result obtained in 2010. In June 2011 spore concentrations were low. The increase did not start until the beginning of July and in comparison with 2010 it was slow. The increase in spore concentration in July 2011 was also lower than in 2010, however the decline was observed again at the end of this month, similarly to July 2010. In 2011, like in 2010, the highest spore concentrations were recorded at the beginning of August, but the high occurrence of spores in the air was observed over a long period of time (approximately for 6 weeks), until mid-September.

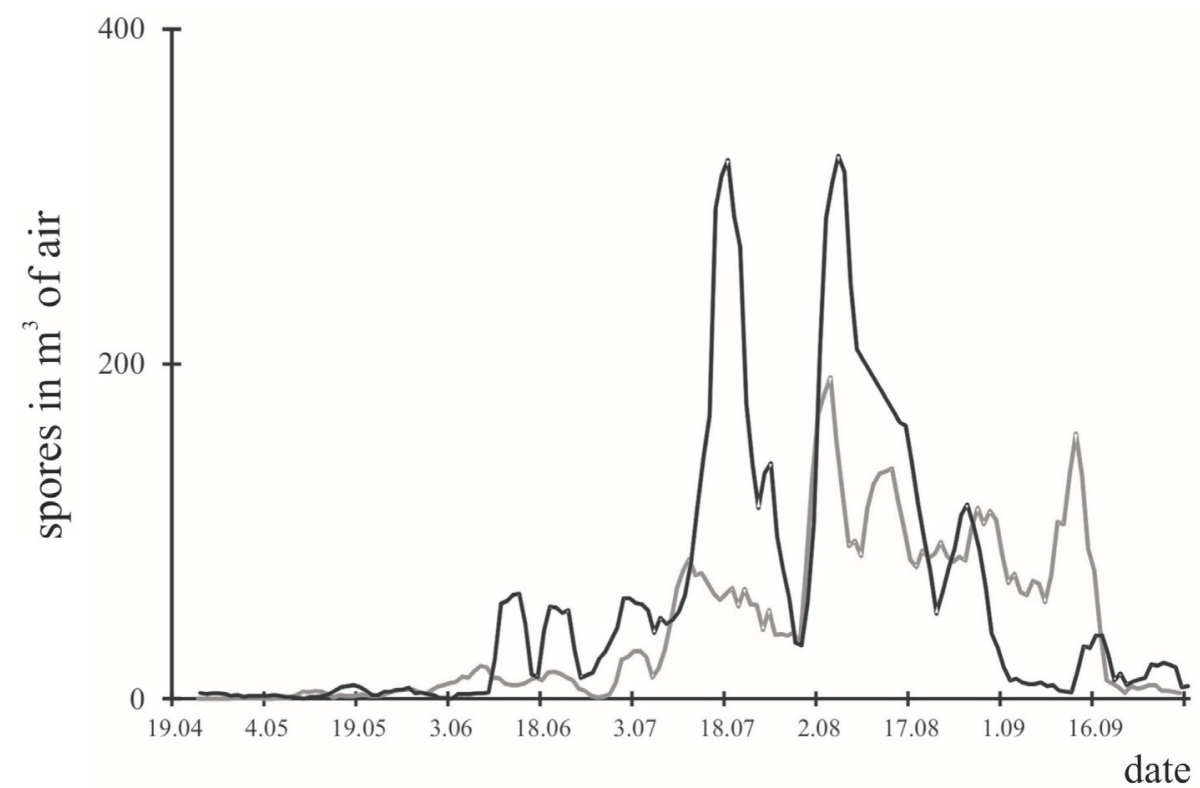

Fig. 1. Fluctuations of Alternaria spores in the air of Rzeszów (Carpathian Foothills, south-east Poland) in 2010 and 2011 expressed as the 5-day moving average; black line - 2010, grey line - 2011.

\section{Lublin}

The periods of spore occurrence in the air were long, irregular and characterized by strong right skewness (Table 1). In 2010, there were three periods of high increase of spore concentration (Fig. 2). It was found in late July, but after a few days the concentration rapidly decreased. Then - similarly to the fluctuation observed in Rzeszów - it gradually increased during the next week and reached the highest amount at the beginning of August. In mid-August, the concentration of Alternaria spores increased for the third time, to the level of the first peak. In 2011, a period of high spore concentration lasted from early August to mid-August with short declines. In September 2011, each increase of Alternaria spore concentrations lasted for a few days. In 2010 and 2011 the seasonal fluctuations of spores in the air were relatively similar, but considerable differences concerned their numbers. In 2010, significantly more spores were observed. In both years, the highest levels of spore concentrations occurred in early August with a difference of three days only, but in 2011 the parameter was more than two times lower. Similarly to the result obtained in Rzeszów, kurtosis was positive, but its value in 2010 was 2.5 -times higher than in 2011. 


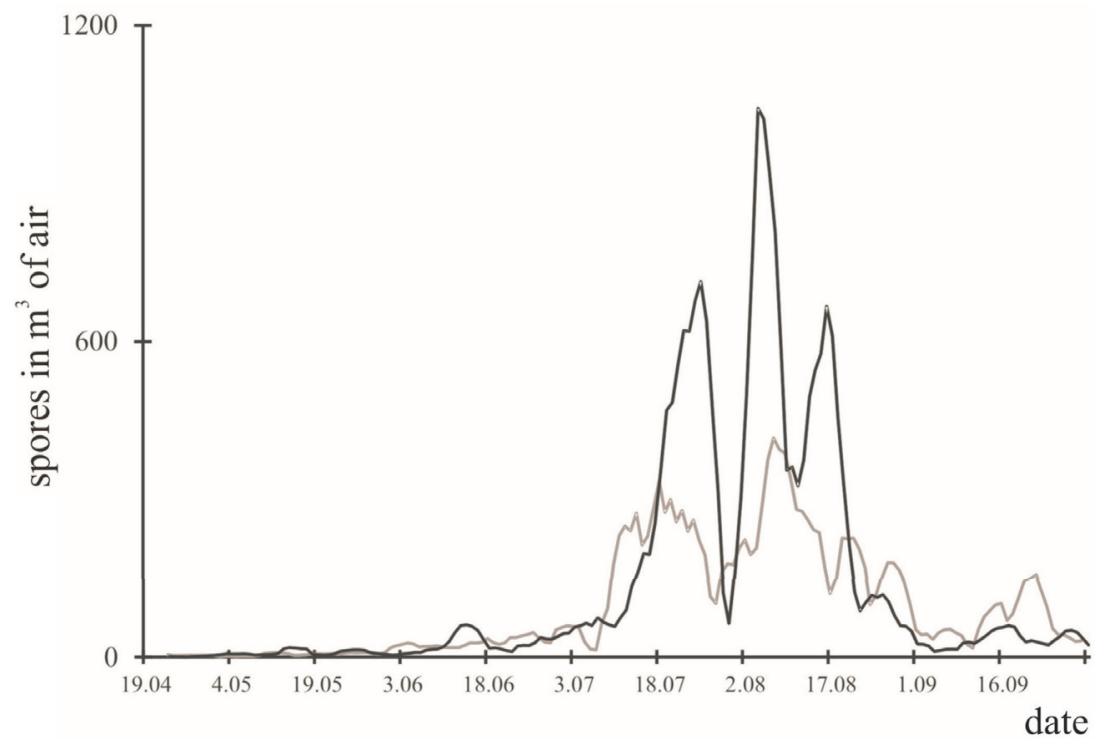

Fig. 2. Fluctuations of Alternaria spores in the air of Lublin (Lublin Upland, central east Poland) in 2010 and 2011 expressed as the 5-day moving average; black line - 2010, grey line - 2011 .

\section{Poznań}

In comparison with the other experimental sites, the period of occurrence of Alternaria spores in the air of Poznan was the most dense (Fig. 3). In 2010, the concentration above 100 spores per cubic meter lasted for 52 days, with a few short decline only. A considerable increase in spore concentration was observed from the beginning of July and the rate of this process was very rapid in the second half of July. The maximum concentration of Alternaria conidiospores was noted on 2 August 2010. Very high concentrations were recorded till the second decade of August. In this month, more than $50 \%$ of all Alternaria spores were observed.
In 2011, two separate periods of high spore concentrations were found. The first period, with lower spore numbers, was recorded from the beginning till the second decade of July. Soon after a sudden decrease, the concentration of spores was again gradually building up. Since the beginning of August, a sudden increase of spore concentration was found and the maximum concentration was recorded soon after - on 5 August. Since the second half of August, the spore concentration steadily decreased and in 2011 it was slightly higher than in 2010. Kurtosis was positive but unlike in Rzeszów and Lublin, its values were high both in 2010 and 2011 (Table 1).

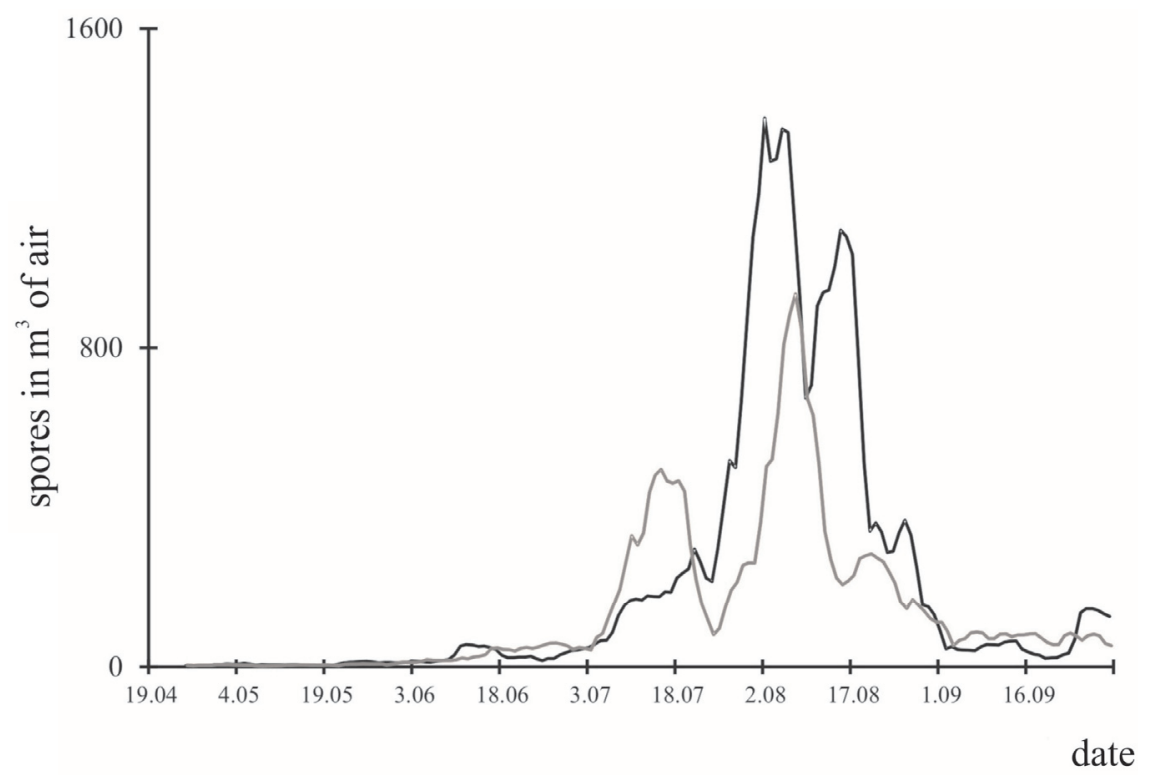

Fig. 3. Fluctuations of Alternaria spores in the air of Poznań (central west Poland) in 2010 and 2011 expressed as the 5-day moving average; black line - 2010, grey line - 2011 . 


\section{Comparison of monitoring sites and years}

The monthly sums of spores differed significantly, between monitoring sites and years. Generally, in 2010 the concentrations of Alternaria spores were always higher than in 2011. The highest spore concen- trations were in August; this was true for each year and at each monitoring site (Table 1). Also, the maximum spore concentration was the highest in August, with the exception of the result of monitoring in Rzeszów in 2010 when the peak spore concentration was in mid-July.

Table 1

Descriptive statistics of the periods of the presence of Alternaria spores in the air of three monitoring sites in Poland (2010-2011)

\begin{tabular}{|c|c|c|c|c|c|c|}
\hline Year & Sum of spores ${ }^{1}$ & $\begin{array}{l}\text { Maximum no. } \\
\text { of spores }^{2}\end{array}$ & $\begin{array}{c}\text { Percent of days } \\
\text { with Alternaria } \\
\text { spores }\end{array}$ & $\begin{array}{c}\text { Day with } \\
\text { maximum no. of } \\
\text { spores }^{3}\end{array}$ & Skewness & Kurtosis \\
\hline \multicolumn{7}{|c|}{ Rzeszów } \\
\hline 2010 & 9769 & 694 & 83.0 & 15 July & 3.12 & 14.14 \\
\hline 2011 & 6943 & 271 & 80.6 & 01 August & 1.72 & 2.95 \\
\hline \multicolumn{7}{|c|}{ Lublin } \\
\hline 2010 & 22258 & 1615 & 92.1 & 03 August & 2.96 & 9.27 \\
\hline 2011 & 15528 & 693 & 95.8 & 06 August & 1.95 & 3.7 \\
\hline \multicolumn{7}{|c|}{ Poznań } \\
\hline 2010 & 34146 & 2295 & 87.9 & 02 August & 2.96 & 8.68 \\
\hline 2011 & 22749 & 1513 & 89.7 & 05 August & 3.42 & 14.6 \\
\hline
\end{tabular}

${ }^{1}$ sum of Alternaria spores in the studied period

${ }^{2}$ the highest number of spores per day

${ }^{3}$ day with the highest number of spores

In Rzeszów, the difference between the sum of spores in July and August 2010 was less substantial, as compared to the differences between the other months (453 spores), with the exception of the difference of 70 spores only between April and May (Fig. 4). The gap between May and June was 907 spores, the difference between June to July was 2874 spores, and between August and September it was as much as 3901 spores. In 2011, the highest difference in cumulative spore concentrations was found between August and September; it was 2031 spores (Fig. 5). Generally, in 2011 in Rzeszów the monthly sums of Alternaria spores, the maximum spore concentration and the total spore concentration were the lowest as compared to the other monitoring sites (Table 1). In the studied period from 15 April to 30 September, the percent of days when spores of Alternaria were present in air samples was similar in both years and varied in a narrow range from 80.6 (2011) to $83.0 \%$ (2010).

In Lublin the general trends were the same: the highest spore concentration and the peak cumulative number of spores were found in August, followed by July. In 2011 spore counts showed the same pattern, but there were fewer spores than in 2010. The highest differences of monthly sums of spores were found between June and July and then between August and September (Figs 4, 5). In the first case, it was a sudden increase of 8300 and 4671 spores, respectively for 2010 and 2011. In the second situation, it was a dramatic drop in spore numbers by 10089 and 4797 spores in 2010 and 2011. In Lublin, the percent of days with the occurrence of Alternaria spores in the air was the highest of all the sites. Again, the range was narrow, from 92.1 to $95.8 \%$ of days in the studied period in 2010 and 2011, respectively.

In Poznań both the cumulative sums of spores over the monitoring period and the maximum spore concentrations were the highest as compared to the other monitoring sites (Table 1). Similarly to Lublin, the highest differences in monthly sums of spores were found between June and July and then between August and September, but the differences were even bigger (Figs 4, 5). Again, at first it was a great increase in the cumulative number of spores of 10713 and 6979 spores in 2010 and 2011, respectively. Between August and September, the cumulative number of spores in 2010 and 2011 dropped down by 17454 and 9072 spores. In 2010, the spores of Alternaria were present on $87.9 \%$ of days of the monitored period and in 2011 they were found on $89.7 \%$ of days. 


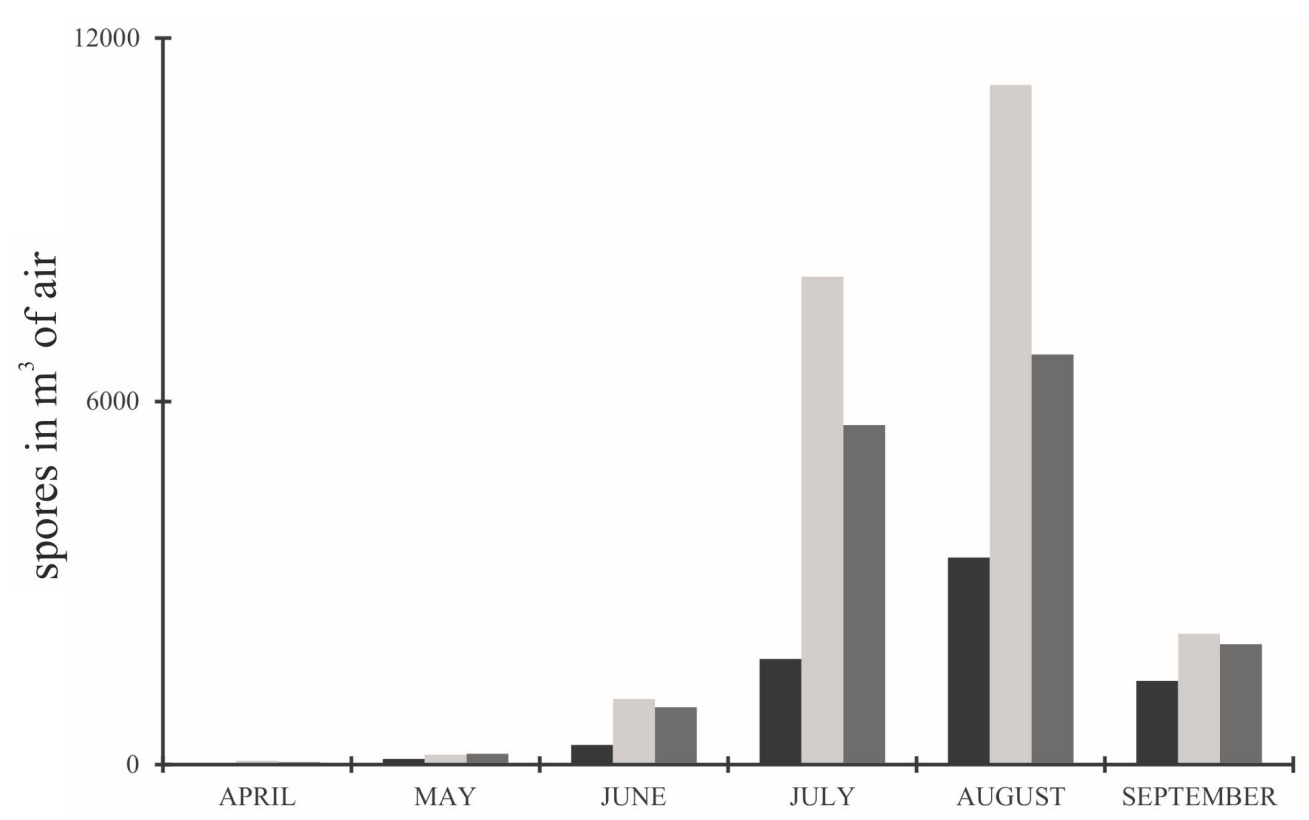

Fig. 4. Monthly sum of Alternaria fungal spores at the three sites studied in 2010, black bars - Rzeszów, light grey - Poznań, and dark grey - Lublin.

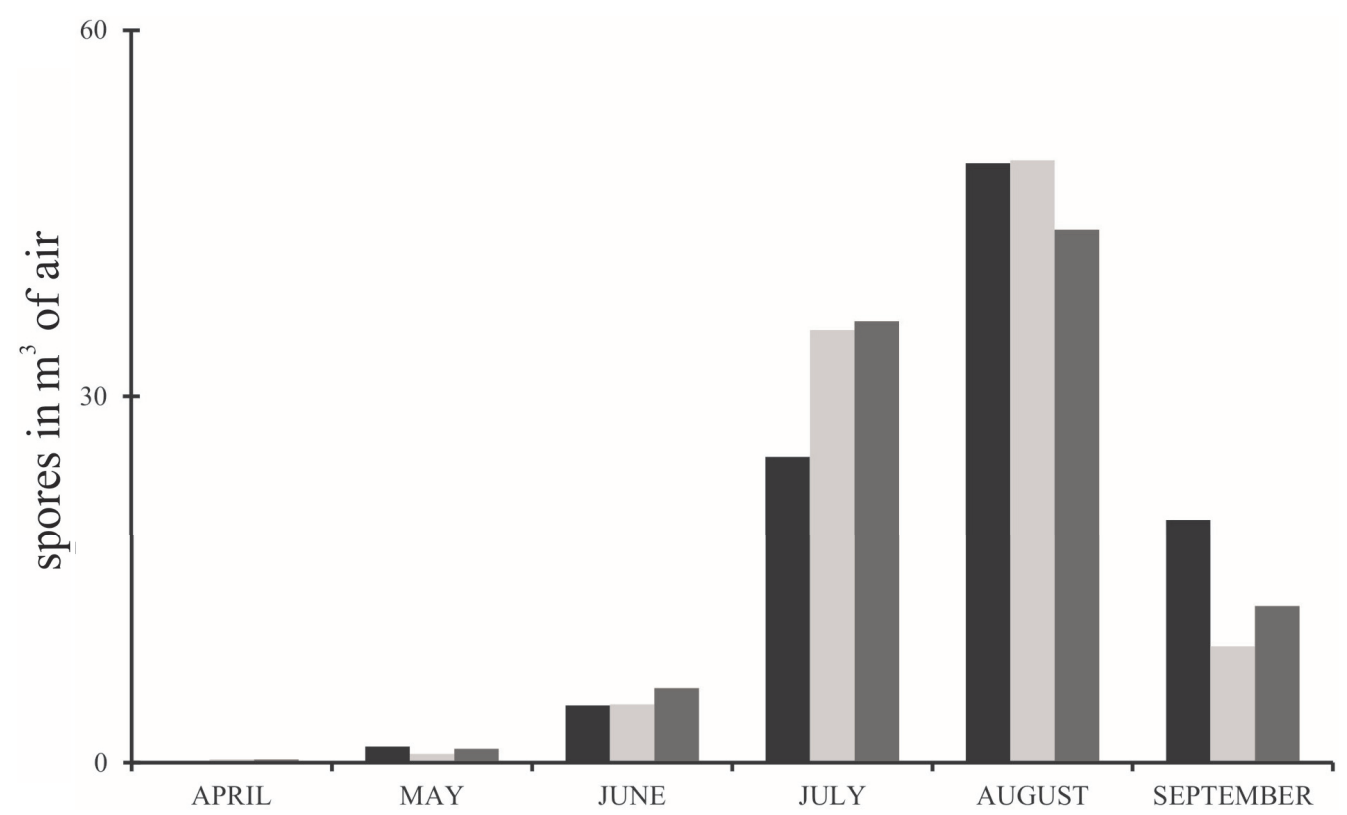

Fig. 5. Monthly sum of Alternaria fungal spores at the three sites studied in 2011: black bars - Rzeszów, light grey - Poznań, and dark grey - Lublin.

Statistically significant differences were found for the concentrations of fungal spores in the following months for all the cities and in both years. However, based on the value of Spearman's rank correlation coefficients, it can be concluded that the dynamics of the presence of spores in the air was to some extent similar at these different monitoring sites (Table 2). The fluctuations of spores were constantly observed over the spring, summer and autumn time, but the spore concentrations increased and decreased at similar, and so- metimes even identical, periods of time. In 2010, these periods of low and high days were relatively similar, especially in Poznań and Lublin where only 1 day lag between the maximum spore concentrations was found. In 2011, the highest concentrations were comparable, with a shift of 5 days only. In 2010, in each city the highest concentration of Alternaria spores was found in August and then in July (the second peak day in Rzeszów). In 2011 the peak concentration of spores was always in August. 
Table 2

Spearman's rank correlation coefficients for daily spore concentrations at the three monitoring sites

\begin{tabular}{ccccc}
\hline \multirow{2}{*}{$\begin{array}{c}\text { Monitoring } \\
\text { site }\end{array}$} & \multicolumn{2}{c}{2010} & \multicolumn{2}{c}{2011} \\
\cline { 2 - 5 } & Poznań & Lublin & Poznań & Lublin \\
\hline Rzeszów & $0.715^{1}$ & 0.784 & 0.697 & 0.696 \\
Poznań & - & 0.781 & - & 0.724 \\
\hline
\end{tabular}

${ }^{1}$ all values were significant at $\leq 0.05$

In both years, the highest concentrations of Alternaria spores were observed in Poznan and the lowest in Rzeszów. In Poznań, the peak concentration was observed in August (2295 spores $/ \mathrm{m}^{3}$ ) and the cumulative number of spores found over the studied season exceeded 43 thousand (Table 2). At all monitoring sites, the annual total, monthly total and maximum concentration were higher in 2010 than in 2011. Multiple comparisons of mean concentrations showed significant differences in 2011 between all sites $(\mathrm{K}-\mathrm{W}$ test, $\mathrm{H}=26.19)$, while in 2010 only between Rzeszów and the other cities $(\mathrm{K}-\mathrm{W}$ test, $\mathrm{H}=15.53)$.

\section{DISCUSSION}

Knowledge about the seasonal and diurnal occurrence of fungal spores in the air and the determination of the influence of various environmental factors on spore concentrations are of great practical importance. Special interest is directed to allergenic and pathogenic fungi, the former being responsible for health problems in humans and animals and the latter for plant diseases. Monitoring of the presence and concentration of airborne spores allows us to better understand the mechanisms of spore dispersal and deposition (M c Cartney, 1994; Myszkowska et al. 2002; R a piejko et al. 2004; Prospero et al. 2005). It is also a useful tool allowing to study the epidemiology of plant diseases caused by plant pathogenic fungi (K a c z mare k et al. 2012; K a r o lew s ki et al. 2012). As a consequence, it helps to undertake appropriate measures to control diseases (W e s t et al. 2001; J ę d r y c z k a et al. 2010).

Conidiospores of Alternaria are very frequent in the air (Corden et al. 2003; Mikali naité et al. 2009; Grinn-Gofroń, 2009). In Poland they occur in air for about $70 \%$ of days of each year (Kasprzyk and Worek, 2006). Considering the fact that the present investigation was done over a shorter period of time, excluding winter, early spring and late autumn when the spore numbers are none or the lowest, our results are in agreement with these reports. We have demonstrated that in the period lasting from mid-April till the end of September spores of Alternaria were present in the air for most of the time.
The lowest percentage frequency was $80.2 \%$ and the highest one was $95.8 \%$, which means that 7 days in Lublin in 2011 and 32 days in Rzeszów, also in the same year, were free from Alternaria. The days with no detection of Alternaria were mostly in April and May. In the following months, such days were rare or nonexistent. During the two years studied, in July and August Alternaria spores were present each day at all three sites. In August 2011 in Poznań the spores were not observed only on 2 days.

In many Polish and European cities the maximum concentration of most fungal spores in aeroplankton, including Alternaria, occurs in summertime and in early autumn (A d a m s , 1964; C ord e n et al. 2003; Stępalska and Wołek, 2005; Myszkowska et al. 2002). According to Nikkels et al. (1996), general trends in the occurrence of airborne spores in different European countries are relatively similar. The authors conclude that it allows the workload put into ongoing aeromycological research to be reduced by removing excessive monitoring points. On the other side, numerous authors point out considerable differences between the sites, both as regards daily spore concentrations and the annual cumulative number of spores ( $\mathrm{S}$ tę palska et al. 1999; Kas przyk et al. 2004; Gri in n- G o fron n, 2008). The main reason are differences in temperature and humidity ( $\mathrm{H}$ a s $\mathrm{n}$ a i $\mathrm{n}, 1993$; Herrero et al. 1996; Angulo-Romero et al. 1999; S ten nett and B egg s, 2004; T o m as se tti et al. 2009; Es curedo et al. 2011) as well as air pollution and sudden weather events, such as summer storms (G r in n - G o f r o ń et al. 2011, 2012). A large portion, but not all, of the variation in spore fluctuations has been explained by now, which makes it difficult to completely trust the forecasting models.

A considerable increase in spore concentration of the genus Alternaria was observed since June. In five out of the six site-years, the peak days were recorded in August; however, in July and at the beginning of September the numbers of spores were also considerably high. Such general trends confirm the observations of other authors (Stępalska et al. 1999; Kasprzyk et al. 2004; Konopińska, 2004; Grinn-Gofroń and Rapiejko, 2009). The variation of sum of spore distribution in following months, different years and at studied locations was substantial.

Similar fluctuations of Alternaria spores in air samples were described by Dutch, British and Lithuanian researchers (Nikkels et al. 1996; Corden et al. 2003; Mikali naité et al. 2009). In Portugal high concentrations of Alternaria were reported later than in Poland - in August and September until the beginning of October (O live i r a et al. 2009). D e Linares et al. (2010) and Maya-Manzano et 
al. (2012), who monitored Alternaria spores in several cities of Spain located in different climatic regions, reported that in northern Spain high concentrations were recorded from July to October. However, in the regions located in southern Spain (Andalusia) two peaks were typically observed, one in the spring and the other one in the autumn. The first increase of spore concentration is reported in May and June, while the second one lasted from September until October. This effect is supported by the differences in weather parameters; in subtropical continental climate summer is hot and dry and in July physiological drought is observed. When temperatures are high and precipitation is minimal, the plant growth is retarded. In contrast, spring and autumn are warm periods with high rainfall (M a r t y n, 2000). In temperate climate typical for Poland, summer is the time of full plant growth. High concentrations of Alternaria spores in July and August coincide with conducive weather and the richness of biological material - the substrate for fungal growth. It must be underlined that fungi from the genus Alternaria are ubiquitous saprotrophs and omnivorous pathogens of numerous plants, including cultivated and wild species, so they find numerous substrates, allowing their fast growth, development and sporulation (Humpherson-Jones, 1989; Awad, 2005; Nowicki et al. 2012).

Additionally to Alternaria spore fluctuations between years, great differences were found between daily spore concentrations. In western and central Europe, these differences were higher than in southern Europe (H e r r e ro et al. 1996; S tę p a l s k a et al. 1999; Angulo-Romero et al. 1999; Kasprzyk et al. 2004; S tępalska and Wołek, 2005; Oliveira et al. 2009). In Amares, located in northern Portugal, the mean annual sum of spores rose up to the peak number of about 4 thousand spores. In Porto situated in the centre of Portugal, this parameter was twice as low. The maximum daily spore concentrations ranged from 50 to 80 spores per $1 \mathrm{~m}^{3}$ (O li v e i r a et al. 2009). During our studies, on 2 August 2010 in Poznań the daily spore concentration was comparable to the annual spore concentration in Amares. In Greece the maximum daily concentrations were higher than in Portugal, but between 1996 and 2002 they hardly ever exceeded 200 spores per $1 \mathrm{~m}^{3}$ (D a mialis and Gioulekas, 2006). In our study, the spore concentrations in each Polish city were much higher than in Portugal or Greece.

The analysis performed in our study has shown that even over 2 years and at 3 sites, which are located from 138 to $441 \mathrm{~km}$ apart, the differences in spore concentrations may be significant. Great fluctuations in aerobiological data are commonly found and typical not only for airborne fungal spores but also for pollen grains. In Szczecin, located in north-west Poland, the observations done over three years (2004-2006) revealed great differences between monthly sums of Alternaria spores (G r i n n - G o f r o ń, 2008). In 2004 the monthly sum of spores in August was much higher than in other months ( $c a .9,000$ spores). In the following year, the cumulative concentration of spores at this level was observed in July $(10,000)$ and then in August $(11,000)$. One year later in July and August, there were approximately 4,000 Alternaria spores. In our study, the highest cumulative number of spores was observed in August 2010.

In Rzeszów, located in south-east Poland, a comparable study was done in 2000-2002 exactly at the same site and height (K a s przyk et al. 2004), which allows direct comparison. Similarly to the results of our monitoring, the highest concentration of spores was observed in summertime. In 2000 and 2002 the maximum concentration was observed at the beginning of August, but in 2001 the peak number of spores was found at the beginning of July. In this study, a similar result was achieved; in 2010 the maximum spore concentration was observed at the beginning of July, but the next year the same parameter was recorded at the beginning of August. The results obtained in 2002 in Rzeszów and Lublin were also compared. The location of the monitoring stations in these cities was exactly the same as the one used in our work, so it was again possible to make direct comparisons. It was found that the mean concentrations differed significantly and the maximum spore concentration in Lublin was twice as high as in Rzeszów (K a s przy k and Ko nopińska, 2006), which was also the case in our study. Four years of study do not allow to draw firm conclusions, but the tendency seems quite clear.

In this study, the highest concentrations of Alternaria spores were found in Poznań. In 1995-1996 Stę palska et al. (1999) monitored spores at five locations in Poland, including Poznań, and there she found the highest concentration of Alternaria spores. In 1995 the highest concentration was recorded in July (over 8,000) and in the following year this value increased dramatically and peaked up to 24,000 spores.

One should also consider whether such differences can be traced back to the type of landscape considered as a holistic system. The landscapes of Rzeszów (the capital of the Carpathian Foothills, a hilly region in south-east Poland, covered with many forests) and Poznań (the capital of Great Poland, located in the central western part of the country - a typical agricultural lowland plain, more densely populated) greatly differ. Great Poland is a region of concentrated agriculture with multi-hectare fields of cereals, oilseed rape, root crops, selected fruit and vegetables. Therefore, the probability of infection with fungal pathogens, including phytopathogens and saprotrophs, is higher in Great Poland than in the Carpathian Foothills, 
with its mosaic of smaller fields and larger forest areas. Large agricultural fields of Great Poland lead to the concentration of manual and mechanical labour; many agrotechnical treatments are done at the same time. In contrast to small fields with many plant cultivars and landraces grown in the Carpathian Foothills, intensive agriculture requires the use of the same cultivar on a large field. It is a prerequisite for even development, as all plants in a large field are at the same growth stage. It is indispensable for the use of heavy machinery, such as harvesters, allowing seeds or other parts of plants to be collected in a short time. This synchronization of farmers' work may be one of probable causes of sudden increases in the occurrence of fungi that are associated with certain growth stages of agricultural crops. Based on a study carried out in Egypt (A w a d, 2005), it must be underlined that plant vegetation is regarded as the main source of Alternaria spores. M i t a kak is et al. (2001) and C ord e n et al. (2003) pointed out that that the concentration of Alternaria spores increased significantly during haymaking and harvesting. In the Carpathian Foothills, the landscape has a more diverse structure than in Great Poland (www.mprn.pl). Fields are smaller, the variety of crops is bigger, there are more pastures, meadows and forests. It would be of great interest to conduct a long-term study on Alternaria as well as on other taxa in more types of landscape, based on inanimate and animate components of the environment.

\section{Acknowledgements}

The project was funded by the National Research Centre project no. N N305 321737.

\section{REFERENCES}

Ad a m s K.F. 1964. Year to year variation in the fungus spore content of the atmosphere. Acta Allergol. 19: 11-50.

Angulo-Romero J., Mediavilla-Molina A., Dominquez-Vilches E. 1999. Conidia of Alternaria in the atmosphere of the city of Cordoba, Spain in relation to meteorological parameters. Int. J. Biometeorol. 43: 45-49.

Aw a d A.H.A. 2005. Vegetation: A source of air fungal biocontaminant. Aerobiologia, 21: 53-61.

Baranowski P., Mazurek W., Jędryczka M., Babula-Skowrońska D. 2009. Temperature changes of oilseed rape (Brassica napus) leaves infected by fungi of Alternaria sp. [in Polish, with an English abstract]. Rośliny Oleiste - Oilseed Crops 30: 21-33.

Bush R.K., Portnoy J.M. 2001. The role and abandament of fungal allergens in allergic diseases. J. Allergy Clin. Immunol. 107: 430-440.

Corden J. M., Millington W. M., Mullins J. 2003. Long term trends and regional variation in the aeloalergen Alternaria in Cardiff and Derby UK- are differences in climate and cereal production having an effect? Aerobiologia, 19: 191-199.

Crook B. 1994. Aerobiological investigation of occupational respiratory allergy in agriculture in the $\mathrm{U} \mathrm{K}$. Grana, 33: 81-84.

D'A mato G., Spieksma F.T.M. 1995. Aerobiologic and clinical aspects of mould allergy in Europe. Allergy, 50: 870-877.

Damialis A., Gioulekas D. 2006. Airborne allergenic fungal spores and meteorological factors in Greece: Forecasting possibilities. Grana, 45: 122-129.

De Lineres C., Belmonte J., Canela M., de la Guardia C.D., Alba-Sanchez F., Sabariego S. 2010. Dispersal patterns of Alternaria conidia in Spain. Agric. Forest. Meteorol. 150: 1491-1500.

Dong Z.G., Liu G.T., Dong Z.M., Qian Y.Z., An Y.H., Miao J., Zhen Y.Z. 1987. Induction of mutagenesis and transformation by the extract of Alternaria alternata isolated from grains in Linxian, China. Carcinogenesis, 8: 989-991.

Dutkiewicz J. 1997. Bacteria and fungi in organic dust as potential health hazard. Ann. Agric. Environ. Med. 4: 11-16.

Emeryk A., Chojna A., Bartkowiak-Emeryk M., Postępski J. 2004. Prevalance of asthma and some respiratory symptoms in the years 1995 and 2001 in schoolchildren from rural regions of Poland. Ann. Agric. Environ. Med. 11: 63-66.

Escuredo O., Seijo M.O., Fernandez-Gonzalez M., Iglesias I. 2011. Effect of meteorological factors on the levels of Alternaria spores on a potato crops. Int. J. Biometeorol. 55: 243-252.

Frencel I., Lewartowska E., Jędryczka M. 1991. The spectrum and severity of fungal diseases in field infections of winter oilseed rape in Poland. A review of the 1980s. IOBC Bulletin, 14: 137-140.

Gannibal P.B., Gasich E.L. 2009. Causal agents of the alternariosis of cruciferous plants in Russia: species composition, geography and ecology. Mycology and Phytopathology, 5 (43): 447-456 (in Russian).

Gravesen S. 1979. Fungi as a cause of allergic disease. Allergy, 34: 135-154.

Grinn-Gofroń A. 2008. The variation in spore concentrations of selected fungal taxa associated with weather conditions in Szczecin, Poland, 2004-2006. Grana, 47 (2): 139-146.

Grinn-G ofroń A. 2009. The spores of Alternaria in aeroplankton and its relationships with the meteorological factors. Acta Agrobot. 62 (1): 3-8.

Grinn-Gofroń A., Rapiejko P. 2009. Occurrence of Cladosporium spp. and Alternaria spp. spores in Western, Northern and Central-Eastern Poland in 2004-2006 and relation to some meteorological factors. Atmos. Res. 93: 747-758.

Grinn-Gofroń A., Strzelczak A. 2008. Artificial neural network models of relationships between Alternaria spores and meteorological factors in Szczecin (Poland). Int. J. Biometeorol. 52: 859-868. 
Grinn-Gofroń A., Strzelczak A. 2012. Changes in concentration of Alternaria and Cladosporium spores during summer storms. Int. J. Biometeorol. DOI 10.1007/ s00484-012-0604-0.

Grinn-Gofroń A, Strzelczak A, Wolski T. 2011. The relationships between air pollutants, meteorological parameters and concentration of airborne fungal spores. Environ. Poll. 159: 602-608.

$\mathrm{H}$ a s n a in S.M. 1993. Influence of meteorological factors on the air spora. Grana, 32: 184-188.

Herrero B., Fombella-Blanco M.A., Fernández-González D., Valencia-Barrera R.M. 1996. The role of meteorological factors in determining the annual variation of Alternaria and Cladosporium spores in the atmosphere of Palencia, 1990-1992. Int. J. Biometeorol. 39: 139-142.

Humpherson-Jones F. M. 1989. Survival of Alternaria brassicae and Alternaria brassicicola on crop debris of oilseed rape and cabbage. Ann. Appl. Biol. 115: 45-50.

Icenhour C.R., Levetin E. 1997. Penicilium and Aspergillus species in the habitats of allergy patients in the Tulsa, Oklahoma area. Aerobiologia, 13: 161-166.

Jędryczka M., Plachká E., Kaczmarek J., Poslušná J., Latunde-Dada A.O., Mączyńska A. 2010. Monitoring of Leptosphaeria maculans and L. biglobosa ascospores around East Sudethian mountains - a joined initiative of Poland and the Czech Republic. Rośliny Oleiste - Oilseed Crops 31: 49-66.

Kaczmarek J., Jędryczka M., Cools H., Fitt B.D.L., Lucas J.A., Latunde-Dada A.O. 2012. Quantitative PCR analysis of abundance of airborne propagules of Leptosphaeria species in air samples from different regions of Poland. Aerobiologia, 28 (2): 199-212.

Karolewski Z., Kaczmarek J., Jędryczka M., Cools H.J., Fraaije B.A., Lucas J.A, Lat unde-Dada A.O. 2012. Detection and quantification of airborne inoculum of Pyrenopeziza brassicae in Polish and U K winter oilseed rape crops by Real-time PCR assays. Grana, 51: 270-279.

Kasprzyk I., Konopińska A. 2006. Comparative analysis of the concentration of fungal spores in the air of Lublin and Rzeszów (Eastern Poland). Acta Agrobot. 59 (2): 143-150.

Kasprzyk I., Rzepowska B., Wasylów M. 2004. Fungal spores in the atmosphere of Rzeszow (south-east Poland). Ann. Agric. Environ. Med. 11: 285-289.

Kasprzyk I., Worek M. 2006. Airborne fungal spores in urban and rural environments in Poland. Aerobiologia, 22: 169-176.

Konopińska A. 2004. Monitoring of Alternaria Ness and Cladosporium Link airborne spores in Lublin (Poland) in 2002. Ann. Agric. Environ. Med. 11: 347-349.

Lacey M, West J.S. 2006. The air spora: a manual for catching and identifying airborne biological particles. Springer-Verlag GmbH, 156.

Licorish K., Novey H.S., Kozak P., Fairshter R.D., Wilson A.F. 1985. Role of Alternaria and Penicili- um spores in the pathogenisis of asthma. J. Allergy Clin. Immunol. 76: 819-825.

Liu G., Qian Y., Zhang P., Dong W., Qi Y., Guo H.T. 1992. Etiological role of Alternaria alternata in human oesophageal cancer. Chin. Med. J. 105: 394-400.

Martyn D. 2000. Klimaty kuli ziemskiej. Państwowe Wydawnictwo Naukowe, 108-112.

Maya-Manzano J.M., Fernández-Rodríguez S., Hernández-Trejo F., Diaz-Perez G., Gonzalo-Garijo A., Silva-Palacios I., MuńozRodríguez A.F., Tormo-Molina R. 2012. Seasonal Mediterranean patterns for airborne spores of Alternaria. Aerobiologia, 28 (4): 515-526.

McCartney H.A. 1994. Dispersal of spores and pollen from crops. Grana, 33: 76-80.

Mikali naité R., Kazlauskas M., Veriankait L. 2009. Prevalence peculiarities of airborne Alternaria genus spores in different areas of Lithuania. Scientific Works of the Lithuanian Institute of Horticulture and Lithuanian University of Agriculture 28 (30): 135-143.

Mitakakis T., Ong E.K., Stevens A., Guest D., K n ox R.B. 1997. Incidence of Cladosporium, Alternaria and total fungal spores in the atmosphere of Melbourne (Australia) over 3 years. Aerobiologia, 13: 83-90.

Mitakakis T.Z., Clift A., McGee P.A. 2001. The effect of local cropping activities and weather on the airborne concentration of allergenic of Alternaria spores in rural Australia. Grana, 40: 230-239.

www.mprn.pl

Myszkowska D., Stępalska D., Obtułowicz K., Porębski G. 2002. The relationship between airborne pollen and fungal spore concentration and seasonal pollen allergy symptoms in Cracow in 1997-1999. Aerobiologia, 18: 153-161.

Nikkels A.H., Terstegge P., Spieksma F.Th.M. 1996. Ten types of microscopically identifiable airborne fungal spores at Leiden, The Netherlands. Aerobiologia, 12: 107-112.

Nowicki M., Nowakowska M., Niezgoda A., Kozik E.U. 2012. Alternaria black spot of crucifers: symptoms, importance of disease and perspectives of resistance breeding. Vegetable Crops Research Bulletin, 76: 5-19.

Ogórek K., Pląskowska E., Kalinowska K. 2011. Charakterystyka i taksonomia grzybów z rodzaju Alternaria. Mikol. Lekarska, 18 (3): 150-155.

Oliveira M., Ribeiro H., Delgado J.L., Abreu I. 2009. The effects of meteorological factors on airborne fungal spore concentration in two areas differing in urbanisation level. Int. J. Biometeorol. 53: 61-73

Ostry V. 2008. Alternaria mycotoxins: an overview of chemical characterization, producers, toxicity, analysis and occurrence in foodstuffs. World Mycotoxin Journal, 1 (2): 175-188.

Piotrowska K., Kaszewski B.M. 2011. Variations in birch (Betula spp.) pollen seasons in Lublin and correlations with meteorological factors in the period 
2001-2010. A preliminary study. Acta Agrobot. 64 (2): 39-50.

Prospero J.M., Blades E., Mathison G., Naidu R. 2005. Interhemispheric transport of viable fungi and bacteria from Africa to the Caribbean with soil dust. Aerobiologia, 21: 1-19.

Rapiejko P., Lipiec A., Wojdas A., Jurkiewicz D. 2004. Threshold pollen concentration necessary to evoke allergic symptoms. Int. Rev. Allergol. Clin. Immunol. 10 (3): 91-94.

Rosas I., Escamilla B., Calderón C., Mosińo P. 1990. The daily variations of airborne fungal spores in Mexico City. Aerobiologia, 6: 153-158.

Sakiyan N., Inceo lu Ö. 2003. Atmospheric concentrations of Cladosporium Link and Alternaria Nees spores in Ankara and the effects of meteorological factors. Turk. J. Bot. 27: 77-81.

Srivastawa A.K., Wadhwani K. 1992. Dispersion and allergenic manifestations of Alternaria airspora. Grana, 31: 61-66.

Stennett P.J., Begg s P. J. 2004. Alternaria spores in the atmosphere of Sydney, Australia, and relationships with meteorological factors. Int. J. Biometeorol. 49: 98-105.

Stępalska D., Grinn-Gofroń A., Piotrowicz K. 2012. Occurrence of Didymella ascospores in western and southern Poland in 2004-2006. Aerobiologia, 28: $153-159$.

Stępalska D., Harmata K., Kasprzyk I., Myszkowska D., Stach A. 1999. Occurrence of airborne Cladosporium and Alternaria spores in Southern and Central Poland in 1995-1996. Aerobiologia, 15: $39-47$.

Stępalska D., Wołek J. 2005. Variation in fungal spore concentrations of selected taxa associated to weather conditions in Cracow, Poland, in 1997. Aerobiologia, 21: 43-52.

Tomasetti B., Angelosante Bruno A., Pace L., Verecchia M., Visconti G. 2009. Prediction of Alternaria and Pleospora concentrations from the meteorological forecast and artificial neural network in L'Aguila, Abruzzo (Central Italy). Aerobiologia, 25: 127-136.

West J.S., Kharbanda P.D., Barbetti M.J., Fitt B.D.L. 2001. Epidemiology and management of Leptosphaeria maculans (phoma stem canker) on oilseed rape in Australia, Canada and Europe. Plant Pathol. 50: 10-27.

Woody M.A.,Chu, F.S. 1992. Toxicology of Alternaria mycotoxins. In: Chełkowski, J. and Visconti, A. (Eds.) Topics in secondary metabolism, vol. 3, Alternaria: biology, plant diseases and metabolites. Elsevier, New York, USA, 409-434.

Woś A. 1999. Klimat Polski. Państwowe Wydawnictwo Naukowe, Warszawa. (in Polish)

Yekeler H., Bitmis K., Ozcelik N., Doymaz M.Z., Calta M. 2001. Analysis of toxic effects of Alternaria toxins on oesophagus of mice by light and electron microscopy. Toxicologic Pathology, 29: 492-497.
Zhen Y.Z., Xu Y.M., Liu G.T., Miao J., Xing Y.D., Zheng Q.L., Ma Y.F., Su T., Wang X.L., Ruan L.R., Tian J.F., Zhou G., Yang S.L. 1991. Mutagenicity of Alternaria alternata and Penicillium cyclopium isolated from grains in an area of high incidence of esophageal cancer - Linxian China. In: O'Neill, I.K., Chen, J. and Bartsch, H. (Eds.) Relevance to human cancer of N-nitroso compounds, tobacco smoke and mycotoxins. International Agency for Research on Cancer, Lyon, France, 253-257.

\section{Zakres wahań stężenia zarodników konidialnych Alternaria w powietrzu z różnych lokalizacji geograficznych w Polsce (2010-2011)}

\section{Streszczenie}

Znajomość sezonowej i dobowej rytmiki występowania alergennych i patogennych zarodników grzybów w powietrzu oraz określenie wpływu elementów środowiska na wartości stężeń mogą być wykorzystane w praktyce, w alergologii i w rolnictwie. Celem badań było określenie dynamiki występowania zarodników Alternaria w powietrzu trzech stanowisk zlokalizowanych $\mathrm{w}$ różnych regionach geograficznych Polski. Badania prowadzono od 15 kwietnia do 30 września w latach 2010-2011 na terenie Rzeszowa, Lublina i Poznania; odległości pomiędzy punktami badawczymi wynosiły od 138 do $441 \mathrm{~km}$. Do oceny stężenia zarodników rodzaju Alternaria zastosowano metodę wolumetryczną. W obu latach najwyższe stężenia zarodników odnotowano w Poznaniu, a najniższe w Rzeszowie. Na wszystkich stanowiskach w 2010 roku miesięczne i roczne sumy zarodników, jak też ich maksymalne stężenie było wyższe niż w 2011 roku. Stężenie zarodników Alternaria było największe w sierpniu i niewiele niższe w lipcu. Wysokie stężenia odnotowano także na początku września. Różnice w dobowych stężeniach, średnich stężeniach i sumach w kolejnych miesiącach w okresie dwóch lat badań były statystycznie istotne. Przyczyny takich wyników można upatrywać nie tylko w przebiegu pogody, co jest często rozważane w literaturze, ale także w typie krajobrazu. Warunki geobotaniczne Wielkopolski i Podkarpacia bardzo się różnią, a krajobraz Lubelszczyzny jest w tym przypadku pośredni, lecz bardziej zbliżony do Wielkopolski. W obu latach największą liczbę zarodników grzybów rodzaju Alternaria stwierdzono w Poznaniu - mieście o największym współczynniku urbanizacji oraz stolicy regionu z rolnictwem wielkoobszarowym, związanym z intensyfikacją zabiegów agrotechnicznych. 